\title{
Do hematologic constituents really increase due to endurance exercise in horses? ${ }^{1}$
}

\author{
Antonio R. Teixeira-Neto², Guilherme C. Ferraz ${ }^{3}$, Augusto R.C. Moscardini' ${ }^{2}$, \\ Raquel M. Albernaz ${ }^{3}$, Milena R. Gondin ${ }^{3}$ and Antonio Queiroz-Neto ${ }^{3 *}$
}

\begin{abstract}
Teixeira-Neto A.R., Ferraz G.C., Moscardini A.R.C., Albernaz R.M., Gondin M.R. \& Queiroz-Neto A. 2012. Do hematologic constituents really increase due to endurance exercise in horses? Pesquisa Veterinária Brasileira 32(9):951-956. Laboratório de Farmacologia e Fisiologia do Exercício Equino, Faculdade de Ciências Agrárias e Veterinárias, Universidade Estadual Paulista, Jaboticabal, SP 14884-900, Brazil. E-mail: aqueiroz@fcav.unesp.br

The aim of this study was to evaluate the behavior of blood constituents in a group of horses that successfully completed long endurance rides in tropical conditions. Jugular vein puncture was done to collect blood before, during and after rides. Data were analyzed using a mathematic approach, based on the hematocrit and blood volume where the percentual change in plasma volume was used to correct the values of each variable analyzed. Significance was inferred when $P<0.05$. The proposed mathematical model to assess blood constituents concentrations allowed the observation of a different pattern of the variables behavior, pointing out that the approach followed by the authors could be more sensitive than ones that did not take this routine. In conclusion, the method used in this study enabled to monitor the physiological processes that actually occur during endurance effort in tropical conditions.
\end{abstract}

INDEX TERMS: Endurance riding, horses, physiologic responses.

RESUMO.- [0 exercício de resistência realmente leva ao aumento dos constituintes sanguíneos em equinos?] Este estudo objetivou avaliar o comportamento dos componentes do sangue em cavalos que concluiram com êxito provas de enduro em condições tropicais. Punção da veia jugular foi realizada para coletar o sangue antes, durante e após o evento. Os dados foram analisados por meio de uma abordagem matemática, com base no hematócrito e volume de sangue onde a variação percentual no volume plasmático foi utilizada para corrigir os valores de cada variável analisada. 0 nível de significância adotado foi $P<0,05$. 0 modelo matemático proposto para avaliar as concentrações de componentes do sangue permitiu a observação de um padrão diferente no comportamento de várias variáveis

\footnotetext{
${ }^{1}$ Received on December 9, 2011.

Accepted for publication on June 28, 2012.

${ }^{2}$ Faculdade de Agronomia e Medicina Veterinária, Campus Universitário Darcy Ribeiro, Universidade de Brasília, Asa Norte, Brasilia, DF 70910900, Brazil.

${ }^{3}$ Laboratório de Farmacologia e Fisiologia do Exercício Equino (Lafeq), Faculdade de Ciências Agrárias e Veterinárias (FCAV), Universidade Estadual Paulista (Unesp), Campus de Jaboticabal, Via de Acesso Prof. Dr. Paulo Donato Castellane s/n, Jaboticabal, SP 14884-900, Brazil. * Corresponding author: aqueiroz@fcav.unesp.br
}

plasmáticas, destacando que a abordagem seguida pelos autores é mais sensível do que aquelas que não seguiram este procedimento. Em conclusão, o método utilizado neste estudo permitiu acompanhar os processos fisiológicos que realmente ocorrem durante o esforço de resistência em condições tropicais.

TERMOS DE INDEXAÇÃO: Enduro, cavalos, respostas fisiológicas.

\section{INTRODUCTION}

Endurance riding is a competition in which the speed and endurance of a horse is tested, and riders are also challenged with regards to the effective use of pace and thorough knowledge of their horses through cross-country. Horses can suffer from dehydration and heat stress (Waller et al. 2009), leading to a large number of clinical disorders indicating that the equine athlete is not prepared for the task. The exercising horse produces a tremendous amount of metabolic heat and, like humans, cools primarily by the evaporation of sweat leading to fluids and electrolytes losses that, if uncompensated for, can lead to cardiovascular and thermoregulatory instability (McKeever 2008). Given the substantial fluid losses incurred during prolonged exercise, it is likely that reductions in plasma volume play 
a greater role in changes in hematocrit (Kingston 2008). In association with the increases in hematocrit are increases in the erythrocyte count, haemoglobin concentration (Kingston 2008), leukocytosis (Rose \& Hodgson 1982, Snow et al. 1982) and some plasma constituints. Indoubtly, haematology and plasma or serum biochemistry are important tools for assessing the health of athletic horses (Kingston 2004).

The extent of increase in haematological variables is a function of exercise duration and intensity. In controlled incremental exercises of short duration, a linear relationship between haematocrit and speed is observed. For instance, as a consequence of an increase in haemoglobin concentration due splenic contraction, there is an increase in oxygen transport capacity, an important factor in the high aerobic capacity of horses. In an endurance effort, two physiological events can contribute to HT elevation: The splenic contraction and, more important the decrease of plasma volume due to sweating (Ferraz et al. 2009).

This field study monitored a group of horses that successfully completed long endurance rides in tropical conditions, determining hematologic, biochemical and body weight alterations before, during and after rides. The aim of this work was to evaluate the behavior of blood constituents, despite percentual plasma volume change, by using a proposed mathematic approach (Beaumont 1972), based on the hematocrit and blood volume.

\section{MATERIALS AND METHODS}

The present work agrees to the "Ethical Principles in Animal Experimentation" adopted by the "Brazilian College of Animal Experimentation" and was approved by the University's Institutional Animal Care and Use Committee.

Eighty Arabians horses (geldings and mares), 7 to $15 \mathrm{yr}$. of age, that successfully complete endurance rides longer than 70 $\mathrm{km}$, during a regional championship divided into 5 stages throughout the year 2004 (May, July, September, October and December). All horses had three to four years of training, and came from different stables and training centers.

Throughout the rides, total number of horses decreased. 44 completed $70 \mathrm{~km}$ distance rides and 22 completed $100 \mathrm{~km}$ rides, while 39 were monitored in the recovery period. These distances were covered with an average speed of $11.8 \pm 0.6 \mathrm{~km} . \mathrm{h}^{-1}$. Eliminated horses did not participate in this study.

The whole study took place in the tropical climate of west central Brazil. Relative humidity and air temperature were registered every hour (from 6:00AM to 6:00PM) and ranged from 27 to $81 \%$, and from 24 to $36^{\circ} \mathrm{C}$, respectively, during the worst period of the day (10:00AM to 4:00PM).

Jugular vein puncture was done to collect blood from horses, into evacuated collection tubes (Vacutainer ${ }^{\circledR}$ Becton Dickinson, Sao Paulo, Brazil) with or without EDTA, before, during and after rides. Blood samples were chilled in crushed ice until laboratory analysis. The first sample was always taken two to five hours before the beginning of each ride, $\mathrm{T}_{0}$ (pre-ride or basal levels); after the completion of each loop and rides $\left(\mathrm{T}_{1}, \mathrm{~T}_{2}, \mathrm{~T}_{3}\right.$ and $\left.\mathrm{T}_{4}\right)$. Timepoints 3 and 4 refered to the ends of 70 and $100 \mathrm{~km}$ rides, respectively. With the purpose of monitoring the recovery of the animals in their stables, blood samples were collected 24, 48 and 72 hours after each ride (recovery period).

The erythrocyte and leukocyte counts (He and Le), haemoglobin concentration $(\mathrm{Hb})$, haematocrit $(\mathrm{HT})$ and total protein
(TP) values were determined automatically by a specific counter (Arcus vet $3^{\circledR}$, Diatron, São Paulo, Brazil). Mean corpuscular volume (MCV) and mean corpuscular haemoglobin concentration (MCHC) values were obtained mathematically. For biochemical analysis, serum samples were used to determine the concentrations of blood urea nitrogen (BUN) and creatinine (Cre) through a kinetic assay employing specific lab kits (Labquest ${ }^{\circledR}$, Labtest Diagnóstica, Lagoa Santa/MG, Brazil). Horses were also weighed with a portable digital scale (Toledo MGR $3000^{\circledR}$, Toledo do Brasil Indústria de Balanças Ltda., São Bernardo do Campo, SP, Brazil) to determine body weight losses (BW) during endurance exercise and the daily amount of restoration in the recovery period, which lasted until 72 hours after the rides.

The effect of exercise on physiologic variables was evaluated statistically by the use of analysis of variance (ANOVA) for repeated measures using the general linear models procedure (SAS Institute Inc., Cary, NC), with the aim of determining significant differences for each step of collection, followed by Tukey's test when necessary. Significance was inferred when $P<0.05$. By using a mathematical approach (Van Beaumont 1972), the percentual change in plasma volume was used to correct the values of each variable for each timepoint. New data were obtained (corrected means) and plotted together with previous ones (finalists), with same statistical analysis. To compare both data (finalists and corrected means) at same timepoints, Student's T test was used with significance inferred when $P<0.05$. Values were given as means \pm SEM.

\section{RESULTS}

Table 1 and Figure 1 show body weight data that were expressed in percentual of body weight losses (BW). The losses increased $(P<0.05)$ at the first timepoint $\left(\mathrm{T}_{1} \sim 30\right.$ $\mathrm{km})$, when compared to basal values, and maintained this pattern until the end of rides. The greatest percentage of loss $(5.34 \pm 0.5 \%)$ was reached at the end of $100 \mathrm{~km}$ rides $\left(\mathrm{T}_{4}\right)$, while at the end of $70 \mathrm{~km}$ rides $\left(\mathrm{T}_{3}\right)$ showed values of $5.09 \pm 0.2 \%$. However highest proportion of losses occurred at $\mathrm{T}_{1}$. During the recovery period, this percentual started to decrease 24 hours after rides, and the body weight returned to pre-ride values only at 72 hours after rides.

The concentration of all variables increased during rides, as can be seen in Table 1, Figure 2 (solid lines). The red cell dependent variables $(\mathrm{He}, \mathrm{Hb}, \mathrm{HT})$ increased $(P<0.05)$ during rides and returned to basal values at the first 24 hours post rides. Data from MCV and MCHC did not reveal any statistical variation throughout the experiment as also shown in Table 1.

Values of total protein (TP) increased over the course of the ride, just not at the same relative rate of change as haematocrit, returning to basal values in $\mathrm{T}_{3}(\sim 70 \mathrm{~km}$ distance $)$. Le, BUN and Cre did change consistently over the rides. Total leukocyte count $(\mathrm{Le})$ revealed an increase $(P<0.05)$ at $\mathrm{T}_{2}$ compared to pre-ride values, and it reached peak levels at $\mathrm{T}_{4}$, returning to basal values 48 hours of recovery period. BUN increased $(P<0.05)$ at $\mathrm{T}_{2}(\sim 50 \mathrm{~km})$, reaching peak values at $\mathrm{T}_{4}$. Creatinin concentration (Cre) increased $(P<0.05)$ right at $\mathrm{T}_{1}$, showing peak values at $\mathrm{T}_{3}$ and returned to basal values just 48 hours after rides.

Table 2 and Figure 2 (dashed lines, corrected means) show data expressed after correcting the blood volume 
Table 1. Mean values \pm standard error of haematological and biochemical parameters and body weight losses before $\left(T_{0}\right)$, during $\left(T_{1}\right.$ to $\left.T_{4}\right)$ and after (recovery period, 24 to 72 hours) endurance rides of 70 and $100 \mathrm{~km}$ distances. $n$ refers to the number of samples at each moment of rides

\begin{tabular}{|c|c|c|c|c|c|c|c|c|}
\hline & $\mathrm{T}_{0}$ (basal) & $\mathrm{T}_{1}(30 \mathrm{~km})$ & $\mathrm{T}_{2}(50 \mathrm{~km})$ & $\mathrm{T}_{3}(70 \mathrm{~km})$ & $\mathrm{T}_{4}(100 \mathrm{~km})$ & 24 hs & $\begin{array}{l}48 \mathrm{hs} \\
\text { recovery period }\end{array}$ & 72 hs \\
\hline $\mathrm{N}$ & 80 & 68 & 52 & 44 & 22 & 29 & 39 & 39 \\
\hline BWL \% & $0^{c}$ & $4.48 \pm 0.2^{\mathrm{a}}$ & $4.84 \pm 0.2^{\mathrm{a}}$ & $5.09 \pm 0.2^{\mathrm{a}}$ & $5.34 \pm 0.5^{\mathrm{a}}$ & $2.11 \pm 0.8^{b}$ & $1.85 \pm 0.5^{\mathrm{b}}$ & $0.06 \pm 0.5^{c}$ \\
\hline He $x 10$ & $9.16 \pm 0.1^{c}$ & $10.39 \pm$ & 11.13 & $10.31 \pm$ & 10.20 & $.76 \pm 0$ & $9.50 \pm 0.2$ & $9.56 \pm$ \\
\hline $\mathrm{Hb} \mathrm{g} / \mathrm{dL}$ & $13.37 \pm c$ & $14.91 \pm$ & $15.64 \pm$ & $14.73 \pm$ & $14.50 \pm$ & $14.38 \pm 0.2^{\mathrm{bc}}$ & $13.83 \pm 0.2^{\mathrm{bc}}$ & $13.88 \pm 0.2^{\mathrm{bc}}$ \\
\hline MCV & $5.98 \pm 0,8^{\mathrm{a}}$ & $46.63 \pm 0$ & $45.96 \pm 0$ & $47.29 \pm 0,7^{\mathrm{a}}$ & $46.33 \pm$ & $46.07 \pm 0.5^{\mathrm{a}}$ & $45.66 \pm 0.4^{\mathrm{a}}$ & $45.58 \pm 0.4^{\mathrm{a}}$ \\
\hline MCHC & $.38 \pm 0,6^{a}$ & $31.21 \pm 0,4^{\mathrm{a}}$ & $30.86 \pm 0,4^{\mathrm{a}}$ & $30.6 \pm 0,4^{\mathrm{a}}$ & $30.9 \pm 0,2^{\mathrm{a}}$ & $32.13 \pm 0.1^{\mathrm{a}}$ & $32.10 \pm 0.2^{\mathrm{a}}$ & $32.02 \pm 0.1^{\mathrm{a}}$ \\
\hline HT \% & $42.39 \pm 0.6^{\mathrm{d}}$ & $48.07 \pm 0.7^{\mathrm{ab}}$ & $51.02 \pm 0.9^{\mathrm{a}}$ & $48.42 \pm 0.8^{\mathrm{ab}}$ & $47.06 \pm 1.1^{\mathrm{bc}}$ & $44.80 \pm 0.7^{\mathrm{bcd}}$ & $43.31 \pm 0.9^{\mathrm{cd}}$ & $43.45 \pm 0.9^{\text {cd }}$ \\
\hline $\mathrm{TP} \mathrm{g}$ & $7.22 \pm 0.1^{\mathrm{bc}}$ & $7.70 \pm 0.1^{\mathrm{a}}$ & $7.87 \pm 0.1^{\mathrm{a}}$ & $7.46 \pm 0.1^{\mathrm{ab}}$ & $7.47 \pm 0.2^{\mathrm{ab}}$ & $7.07 \pm 0.1^{\mathrm{bc}}$ & $6.84 \pm 0.1^{\mathrm{c}}$ & $6.82 \pm 0.1^{\mathrm{c}}$ \\
\hline Le $x 10^{6} / \mathrm{u}$ & $10.13 \pm 0.2^{\mathrm{ef}}$ & $10.6 \pm 0.3^{\text {def }}$ & $13.23 \pm 0.4^{\mathrm{bc}}$ & $14.5 \pm 0.4^{\mathrm{ab}}$ & $15.7 \pm 0.7^{\mathrm{a}}$ & $11.9 \pm 0.3^{\text {cd }}$ & $11.3 \pm 0.3^{\mathrm{de}}$ & $9.6 \pm 0.29^{f}$ \\
\hline BUN g/dL & $27.44 \pm 0.6^{\mathrm{e}}$ & $30.19 \pm 1.0^{\text {de }}$ & $35.96 \pm 1.4^{\mathrm{bcd}}$ & $42.56 \pm 1.7^{\mathrm{ab}}$ & $46.64 \pm 3.0^{\mathrm{a}}$ & $39.66 \pm 2.8^{\mathrm{abc}}$ & $35.78 \pm 2.0^{\mathrm{cd}}$ & $35.34 \pm 2^{\text {cd }}$ \\
\hline Cre g/dL & $1.33 \pm 0.02^{\mathrm{b}}$ & $1.59 \pm 0.03^{\mathrm{a}}$ & $1.63 \pm 0.08^{\mathrm{a}}$ & $1.73 \pm 0.09^{\mathrm{a}}$ & $1.72 \pm 0.11^{\mathrm{a}}$ & $1.59 \pm 0.07^{\mathrm{a}}$ & $1.33 \pm 0.05^{\mathrm{b}}$ & $1.28 \pm 0.06^{\mathrm{b}}$ \\
\hline
\end{tabular}

Superscript letters indicate statistically different mean $(\mathrm{P}<0.05)$ amongst variables throughout and post rides.

Different $n$ values throughout rides are due to elimination of some horses. The different $n$ values during the recovery period are due to stable personnel problems.

For BW loss the number of horses follows: 49 for $\mathrm{T}_{0} .47$ for $\mathrm{T}_{1} .45$ for $\mathrm{T}_{2}$. 45 for $\mathrm{T}_{3} .21$ for $\mathrm{T}_{4}$. In the recovery period: 15 at 24 hours, 31 at 48 hours and 31 at 72 hours after rides.

Abbreviations: Body weight loss (BWL), Erythrocyte count (He), haemoglobin concentration (Hb), mean corpuscular volume (MCV), mean corpurscular haemoglobin concentration (MCHC), haematocrit (Ht), total plasma protein (TP), total leucocyte count (Le), blood urea nitrogen (BUN) and creatinine (Cre) concentrations.

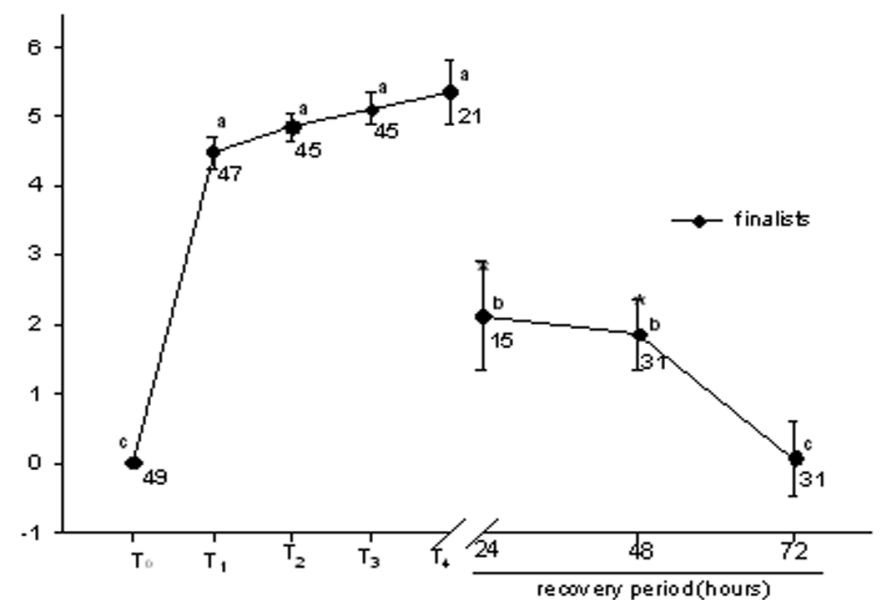

Fig.1. Graphic representation of body weight losses (\%) before $\left(\mathrm{T}_{0}\right)$, during ( $\mathrm{T}_{1}$ to $\mathrm{T}_{4}$ ) and after (recovery period, 24 to 72 hours) a long distance endurance rides in a tropical climate. Data are expressed as means value \pm SEM. Different letters indicate difference $(P<0.05)$ in Tukey's test. by percentual losses of plasma volume in each timepoint. These values were obtained as described by Van Beaumont (1972), and were 1.00 (100\% - zero losses) for $\mathrm{T}_{0}, 0.79$, $0.71,0.78,0.83,0.91,0.96$ and 0.96 for $\mathrm{T}_{1}, \mathrm{~T}_{2}, \mathrm{~T}_{3}, \mathrm{~T}_{4}, 24,48$ and 72 hours post rides, respectively. Interestingly, $\mathrm{He}, \mathrm{Hb}$ and HT showed a decrease $(P<0.05)$ right in $\mathrm{T}_{1}, \mathrm{~T}_{2}$ and $\mathrm{T}_{3}$, returning to basal values in $\mathrm{T}_{4}$. TP also decreased $(P<0.05)$ at $\mathrm{T}_{1}$ and maintained this pattern until the end of the experiment. Le increased $(P<0.05)$ in $\mathrm{T}_{3}$ and $\mathrm{T}_{4}$, returning to basal levels 24 hours post rides. BUN increased $(P<0.05)$ for $100 \mathrm{~km}$ finalists, but remained increased until the end of experiment ( 72 hours). Cre did not change throughout experiment, by this approach.

In Figure 2, when finalists means data (solid lines) were compared to corrected means (dashed lines) at the same timepoints (Student's $T$ test), it was noticed diverging results $(P<0.05)$ for all variables during rides. TP revealed different patterns $(P<0.05)$ throughout the experiment.

Table 2. Corrected mean values \pm standard error of haematological, biochemical parameters and body weight losses before $\left(T_{0}\right)$, during $\left(T_{1}\right.$ to $\left.T_{4}\right)$ and after (recovery period, 24 to 72 hours) long distance endurance rides in a tropical climate. $n$ refers to the number of samples at each moment of rides

\begin{tabular}{|c|c|c|c|c|c|c|c|c|}
\hline Variable & $\mathrm{T}_{0}$ (basal) & $\mathrm{T}_{1}(30 \mathrm{~km})$ & $\mathrm{T}_{2}(50 \mathrm{~km})$ & $\mathrm{T}_{3}(70 \mathrm{~km})$ & $\mathrm{T}_{4}(100 \mathrm{~km})$ & $24 \mathrm{hs}$ & $\begin{array}{l}48 \mathrm{hs} \\
\text { recovery period }\end{array}$ & $72 \mathrm{hs}$ \\
\hline $\mathrm{N}$ & 80 & 68 & 52 & 44 & 22 & 29 & 39 & 39 \\
\hline He $\times 10^{6} / \mathrm{uL}$ & $9.16 \pm 0.1^{\mathrm{a}}$ & $8.16 \pm 0.1^{\mathrm{bc}}$ & $7,91 \pm 0.1^{\mathrm{c}}$ & $8,04 \pm 0.1^{c}$ & $8.46 \pm 0.2^{\mathrm{abc}}$ & $8.88 \pm 0.2^{\mathrm{ab}}$ & $9.12 \pm 0.2^{\mathrm{a}}$ & $9.17 \pm 0.2^{\mathrm{a}}$ \\
\hline $\mathrm{Hb} \mathrm{g/dL}$ & $13.37 \pm$ & $11.72 \pm 0.1^{\mathrm{c}}$ & $11.11 \pm 0.2^{\mathrm{bc}}$ & $11.49 \pm 0.1^{\mathrm{b}}$ & $12.04 \pm 0.2^{\mathrm{a}}$ & $13.09 \pm 0.2^{\mathrm{a}}$ & $13.28 \pm 0.2^{\mathrm{a}}$ & $13.33 \pm 0.2^{\mathrm{a}}$ \\
\hline HT \% & $42.39 \pm 0.6^{\mathrm{a}}$ & $37.77 \pm 0.5^{\mathrm{bc}}$ & $36.22 \pm 0.6^{c}$ & $37.77 \pm 0.6^{b c}$ & $39.06 \pm 0.9^{\mathrm{abc}}$ & $40.77 \pm 0.7^{\mathrm{ab}}$ & $41.58 \pm 0.9^{\mathrm{a}}$ & $41.71 \pm 0.9^{\mathrm{a}}$ \\
\hline TP g/dL & $7.22 \pm 0.1^{\mathrm{a}}$ & $6.08 \pm 0.1^{\mathrm{de}}$ & $5.58 \pm 0.1^{\mathrm{f}}$ & $5.82 \pm 0.1^{\mathrm{ef}}$ & $6.2 \pm 0.2^{\text {cd }}$ & $6.43 \pm 0.1^{\mathrm{bcd}}$ & $6.57 \pm 0.1^{\mathrm{b}}$ & $6.55 \pm 0.1^{\mathrm{bc}}$ \\
\hline Le $\times 10^{6} / \mathrm{uL}$ & $10.13 \pm 2.1^{\mathrm{cd}}$ & $8.37 \pm 2.6^{\mathrm{d}}$ & $9.39 \pm 3.2^{\mathrm{d}}$ & $11.29 \pm 3.1^{\mathrm{b}}$ & $13.05 \pm 6.3^{\mathrm{a}}$ & $10.83 \pm 3.0^{\mathrm{bc}}$ & $10.9 \pm 3.1^{\mathrm{bc}}$ & $9.2 \pm 2.8^{\mathrm{d}}$ \\
\hline BUN g/dL & $27.44 \pm 0.6^{\mathrm{bc}}$ & $23.85 \pm 0.8^{\mathrm{c}}$ & $25.53 \pm 0.9^{c}$ & $33.2 \pm 1.3^{\mathrm{ab}}$ & $38.7 \pm 2.5^{\mathrm{a}}$ & $36.1 \pm 2.5^{\mathrm{a}}$ & $33.7 \pm 1.9^{\mathrm{a}}$ & $33.9 \pm 1.9^{\mathrm{a}}$ \\
\hline Cre g/dL & $1.33 \pm 0.02^{\mathrm{abc}}$ & $1.26 \pm 0.03^{\mathrm{abc}}$ & $1.16 \pm 0.05^{c}$ & $1.35 \pm 0.07^{\mathrm{abc}}$ & $1.43 \pm 0.1^{\mathrm{ab}}$ & $1.45 \pm 0.06^{\mathrm{a}}$ & $1.28 \pm 0.05^{\mathrm{abc}}$ & $1.23 \pm 0.05^{\mathrm{bc}}$ \\
\hline
\end{tabular}

Superscript letters indicate statistically different mean $(\mathrm{P}<0.05)$ amongst variables throughout and post rides.

Different $n$ values throughout rides are due to elimination of some horses. The different $n$ values during the recovery period are due to stable personnel problems.

Abbreviations: Erythrocyte count (He), haemoglobin concentration ( $\mathrm{Hb})$, Haematocrit $(\mathrm{Ht})$, total plasma protein (TP), total leucocyte count (Le), blood urea nitrogen (BUN) and creatinine (Cre) concentrations. 

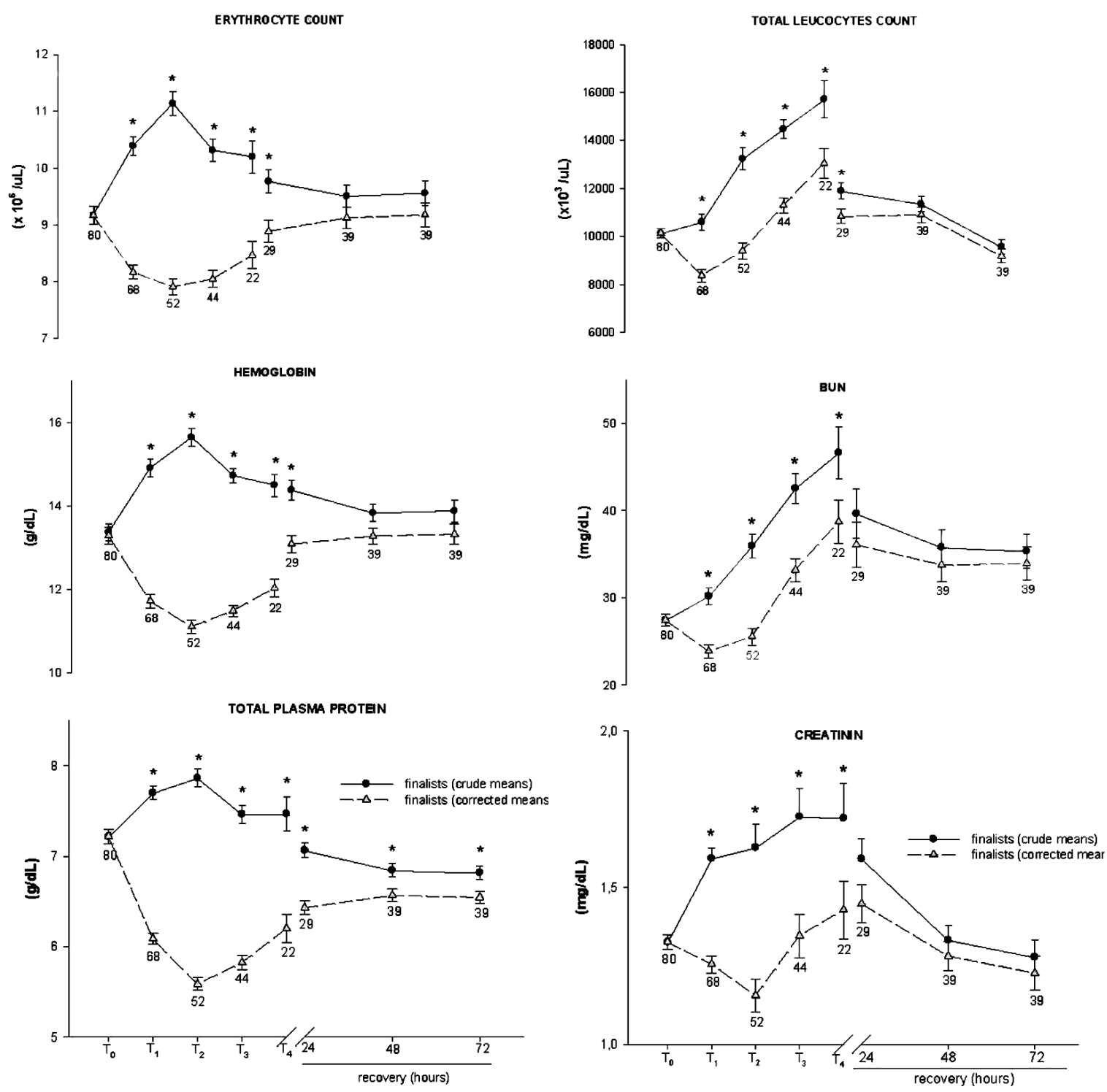

Fig.2. Graphic representation of haematologic and biochemical determinations before $\left(\mathrm{T}_{0}\right)$, during $\left(\mathrm{T}_{1}\right.$ to $\left.\mathrm{T}_{4}\right)$ and after (recovery period, 24 to 72 hours) long distance endurance rides in a tropical climate. Data are expressed as mean value \pm SEM. Corrected means curve indicates values obtained through application of correction factor for each timepoint as follows: $\mathrm{T}_{1}: 0,79 ; \mathrm{T}_{2}: 0,71 ; \mathrm{T}_{3}: 0,78 ; \mathrm{T}_{4}: 0,83 ; 24 \mathrm{hs:} 0,91 ; 48 \mathrm{hs:} 0,96 ; 72 \mathrm{hs:} 0,96 .{ }^{*}$ Indicates statistically different mean $(\mathrm{P}<0.05)$ when compared different curves (full and dashed lines) in the same timepoint. Numbers of animals are showed in each timepoint.

\section{DISCUSSION}

Body weight loss, higher than $5 \%$ were observed in the present study, with significant losses occurring in the first $30 \mathrm{~km}$ of the ride. The body weight returned to pre ride values just at 72 hours after rides. Data also revealed that prolonging the exercise was not sufficient to significantly decrease BW in horses completing $100 \mathrm{~km}$ rather than 70 $\mathrm{km}$ distance.

In 80 and $160 \mathrm{~km}$ distance rides, fluid losses of 3 to $4 \%$ were common and remained after an overnight recovery period (Schott et al. 1997). Similarly, horses submitted to a treadmill-simulated endurance exercise, had BW losses of $3 \%$ despite frequent access to water between exercise sessions (Dusterdieck et al. 1999). These studies differed from the present one in that the environmental conditions could have been less intense or the horses did not have the same access to water or time enough to drink it. Certainly, if horses were weighed before free access to water at each vet point, measured body weight losses would have been higher.

Increases in haematological variables are mainly due splenic reserve mobilisation of erythrocytes, activated by sympathetic stimulation, and is intensity-dependent. Endurance rides happen at a lower intensity than thoroughbred racing (Hoffman et al. 2002). In endurance efforts, two physiological events can contribute to HT elevation. Splenic contraction due to an adrenergic stimulus (Snow et al. 1992) and sweating leading to extense body fluid losses, in more prolonged exercises. As thermoregulation leads to intense sweating with evident body fluids losses and haemoconcentration (Waller et al. 2009). 
$\mathrm{He}, \mathrm{Hb}$ and $\mathrm{HT}$ values showed the relationship with haemoconcentration during rides while its values increased right at the first timepoint of rides and returned to basal values 24 hours after the exercise was completed. By the way, if percentual change of plasma volume is considered, as proposed by Van Beaumont (1972), a different pattern was revealed by these variables. For instance, He and $\mathrm{Hb}$ showed a marked decrease throughout rides, suggesting that red blood cells could be redistributed in endurance effort. By the fact that these values returned to basal ones before the end of rides and MCV and MCHC did not alter, erythrocytes deformability were not supposed to happen, differing from some authors (Smith et al. 1989, Geor et al. 1994, Kingston 2008).

During prolonged, low-intensity exercise, the albumin and total plasma protein concentrations increases (Kingston 2004). Although increased plasma volume has been noticed in dehydrated horses after 40 minutes of low intensity exercise, it is likely that plasma volume decreases in response to the substantial fluid losses incurred during prolonged endurance exercise (Naylor et al. 1993). Furthermore, those fluid losses result in increases in albumin and plasma protein concentrations that are much greater than those observed in horses performing short-duration exercise, and it takes longer for plasma protein concentrations to return to normal following prolonged endurance exercise (Kingston 2004). However, it was noticed in the present study, that total plasma protein did return to basal or pre ride values at the end of $70 \mathrm{~km}$ rides. When percentual plasma change was considered, total protein values revealed a decrease right in the first timepoint of rides, remaining decreased until the end of the experiment.

Exercise can make amino acids available by changing protein turnover either by increasing protein degradation or by reducing protein synthesis (Booth and Watson 1985). In human athletes, protein is generally believed to contribute 5 to $10 \%$ of the total energy demand in prolonged exercise (Broad et al. 2008), with branched-chain amino acid (BCAA) oxidation making the major contribution. According to a study (Assenza et al. 2004), BCAA reduction in endurance horses can contribute to the beginning of central nervous system fatigue. These studies figure out what could occur to total protein in the present study, pointing out that the approach followed by the authors could be more sensitive than ones that did not consider percentual plasma change.

Increases in BUN, during and until the end of recovery period, gives additional evidence of the importance of the amino acid catabolism during exercise (Broad et al. 2008).

Prolonged exercise, such as endurance riding, is associated with leukocytosis resulting from a neutrophilia and lymphopenia (Rose \& Hodgson 1982). This is probably due to an increase in circulating corticosteroids (Dybdal et al. 1980). Data from the present study revealed an increase in Le during rides, and could be seen even when the concentrations were corrected considering the plasma losses, returning to basal values 48 hours after rides, differing from previous researches (Rose \& Hodgson 1982).

Creatinine concentration increased in $\mathrm{T}_{1}$, maintaining this pattern until 48 hours after rides. Previous studies found similar results in $30 \mathrm{~km}$ endurance rides with controlled effort (Fernandes \& Larsson 2000). They affirmed that creatinine elevation during prolonged exercise occurs due to altered renal function (leading to glomerular filtration rate decrease), which are associated with important fluid losses that happen during this type of exercise. This pattern was not observed when the plasma volume was corrected. It was noticed that the effort did not cause variations of creatinine concentrations.

\section{CONCLUSION}

Alterations in hematocrit occur in a lower proportion than plasma volume adjustment. When plasma volume decrease was considered, a better idea of what really occurs with some blood constituents is revealed. Red blood cells redistribution and plasma proteins consumption for energy production could be noticed.

\section{REFERENCES}

Assenza A., Bergero D., Tarantola M., Piccione G. \& Caola G. 2004. Blood serum branched chain amino acids and tryptophan modifications in horses competing in long-distance rides of different length. J. Anim. Physiol. Nutr. 88:172-177.

Beaumont W.V. 1972. Evaluation of hemoconcentration from hematocrit measurement. J. Appl. Physiol. 32:712-713.

Booth F.W. \& Watson P.A. 1985. Control of adaptations in protein levels in response to exercise. Fed. Proc. 44:2293-2300.

Broad E.M., Maughan R.J. \& Galloway S.D.R. 2008. Carbohydrate, protein, and fat metabolism during exercise after oral carnitine supplementation in humans. Intern. J. Sport. Nutr. Exerc. Metabol. 18:567-584.

Dusterdieck K.F., Schott II H.C., Eberhart S.W., Woody K.A. \& Coenen M. 1999. Electrolyte and glycerol supplementation improve water intake by horses performing a simulated $60 \mathrm{~km}$ endurance ride. Equine Vet. J. 30:418-424.

Dybdal N.O., Gribble D., Madigan J.E. \& Stabenfeldt G.H. 1980. Alterations in plasma corticosteroids, insulin and selected metabolites in horses used in endurance rides. Equine Vet. J. 12:137-140.

Fernandes W.R. \& Larsson M.H.M.A. 2000. Alterações nas concentrações séricas de glicose, sódio, potássio, uréia e creatinina, em eqüinos submetidos a provas de enduro de $30 \mathrm{~km}$ com velocidade controlada. Ciênc. Rural 30:393-398.

Ferraz G.C., Teixeira-Neto A.R., Dangelis F.H.F., Lacerda-Neto J.C. \& Queiroz-Neto A. 2009. Alterações hematológicas e cardíacas em cavalos Árabes submetidos ao teste de esforço crescente em esteira rolante. Braz. J. Vet. Res. Anim. Sci. 46:431-437.

Geor R.J., Weiss D.J. \& Smith II C.M. 1994. Hemorheologic alterations induced by incremental treadmill exercise in thoroughbreds. Am. J. Vet. Res. 55(6):854-861.

Hoffman R.M., Hess T.M., Williams C.A., Kronfeld D.S., Griewe-Crandell K.M., Waldron J.E., Graham-Thiers P.M., Gay L.S., Splan R.K., Saker K.E. \& Harris P.A. 2002. Speed associated with plasma pH, oxygen content, total protein and BUN in $80 \mathrm{~km}$ race. Equine Vet. J. 34 (Suppl.): 39-43.

Kingston J.K. 2004. Hematologic and serum biochemical responses to exercise and training, p.939-948. In: Hinchcliff K.W., Kaneps A.J. \& Geor R.J. (Eds), Equine Sports Medicine and Surgery: Basic and clinical sciences of the equine athlete. W.B. Saunders, London.

Kingston J.K. 2008. Hematologic and serum biochemical responses to exercise and training, p.398-422. In: Hinchcliff K.W., Geor R.J. \& Kaneps A.J. (Eds), Equine Exercise Physiology: The science of exercise in the athletic horse. Ed: W.B. Saunders, London.

McKeever K.H. 2008. Body fluids and electrolytes: Responses to exercise and training, p.328-396. In: Hinchcliff K.W., Geor R.J. \& Kaneps A.J. (Eds), 
Equine Exercise Physiology: The science of exercise in the athletic horse. W.B. Saunders, London

Naylor J.R., Bayly W.M., Schott II H.C., Gollnick P.D. \& Hodgson D.R. 1993. Equine plasma and blood volumes decrease with dehydration but subsequently increase with exercise. J. Appl. Physiol. 75:1002-1008.

Rose R.J. \& Hodgson D.R. 1982. Hematological and plasma biochemical parameters in endurance horses during training. Equine Vet. J. 14:144148.

Schott II H.C., McGlade K.S., Molander H.A., Leroux A.J. \& Hines M.T. 1997. Body weight, fluid, electrolyte and hormonal changes in horses competing in 50 and 100 mile endurance rides. Am. J. Vet. Res. 58:303-309.

Snow D.H., Kerr M.G., Nimmo M.A. \& Abbott E.M. 1982. Alterations in blood, sweat, urine and muscle composition during prolonged exercise in the horse. Vet. Rec. 110:377-384.

Snow D.H., Harris R.C., MacDonald I.A., Forster C.D \& Marlin D.J. 1992. Effects of high-intensity exercise on plasma catecholamines in the thoroughbred horse. Equine Vet. J. 24:462-467.

Smith J.E., Erickson H.H., Debowes R.M. \& Clark M. 1989. Changes in circulating equine erythrocytes induced by brief, high-speed exercise. Equine Vet. J. 21(6):444-446.

Waller A.P., Heigenhauser G.J.F., Geor R.J., Spriet L.L. \& Lindinger M.I. 2009. Fluid and electrolyte supplementation after prolonged moderate-intensity exercise enhances muscle glycogen resynthesis in Standardbred horses. J. Appl. Physiol. 106:91-100. 